\title{
Synthesis, Enzyme Assays and Molecular Docking Studies of Fluorinated Bioisosteres of Santacruzamate A as Potential HDAC Tracers
}

\author{
Muneer Ahamed $^{\dagger, \mathrm{a}}$, Koen Vermeulen ${ }^{\dagger, \mathrm{a}}$, Michael Schnekenburger ${ }^{\mathrm{b}}$, Lise Román Moltzau ${ }^{\mathrm{c}, \mathrm{h}}$, \\ Finn Olav Levy ${ }^{\mathrm{c}, \mathrm{h}}$, János Marton ${ }^{\mathrm{g}}$, Mathy Froeyen ${ }^{\mathrm{d}}$, Dag Erlend Olberg ${ }^{\mathrm{e}}$, Marc Diederich ${ }^{\mathrm{f}}$ \\ and Guy Bormans ${ }^{\mathrm{a}, *}$
}

\begin{abstract}
${ }^{a}$ Laboratory of Radiopharmaceutical Research, KU Leuven, Leuven, Belgium; ${ }^{b}$ Laboratoire de Biologie Moléculaire et Cellulaire du Cancer, Hôpital Kirchberg, 9, rue Edward Steichen, L-2540 Luxembourg, Luxembourg; ${ }^{c}$ Department of Pharmacology, Institute of Clinical Medicine, University of Oslo and Oslo University Hospital, Oslo, Norway; ${ }^{d}$ Laboratory for Medicinal Chemistry, Rega Institute of Medical Research, KU Leuven, Leuven, Belgium; ${ }^{e}$ School of Pharmacy, University of Oslo and Norwegian Medical Cyclotron Centre, Oslo, Norway; ${ }^{f}$ Department of Pharmacy, Research Institute of Pharmaceutical Sciences, College of Pharmacy, Seoul National University, Seoul, Republic of Korea and Tumor Microenvironment Global Core Research Center, College of Pharmacy, Seoul National University, Seoul 151-742, South Korea; ${ }^{g}$ ABX advanced biochemical compounds, Biomedizinische Forschungsreagenzien GmbH, Radeberg, Germany; ${ }^{h}$ Center for Heart Failure Research, Faculty of Medicine, University of Oslo, Oslo, Norway
\end{abstract}

A R T I C L E H I S T O R Y
Received: September 15,2016
Revised: October 21, 2016
Accepted: October 24, 2016
DOI:
10.2174/1570180813666161101152943

Keywords: HDAC inhibitors, enzyme assays, molecular docking, PET tracers.

\begin{abstract}
Histone deacetylases (HDACs) emerged as important epigenetic regulators of gene expression. In order to identify potential positron emission tomography (PET) tracers for imaging HDACs, we evaluated in vitro and in cellulo activities of some compounds that were reported as potent HDAC2-selective inhibitors. We observed marked differences between reported activity values and the values obtained in our assays for some of the compounds. To understand the structural basis of the activity of some of these inhibitors, we also performed molecular docking studies to understand their interaction patterns and binding modes with HDAC2. We observed the low affinity compounds 4, 6 and 7 did not showed equal number of key $\pi-\pi$ interactions and hydrogen bonding when compared to high affinity compounds, and could be the possible reason for poor inhibition as reflected in in vitro assays. These preliminary experimental and computational results will help to interpret the HDAC affinity values of these key compounds with caution.
\end{abstract}

\section{INTRODUCTION}

Histone deacetylases (HDACs) are essential posttranslational regulators responsible for deacetylation of acetylated lysine residues in histone and non-histone substrates $[1,2]$. HDACs are divided into four major classes: class I (HDAC1, 2, 3 and 8), class II (HDAC4, 5, 6, 7, 9 and 10), class III also called sirtuins (SIRT1 to 7) and class IV (HDAC11). All of them are $\mathrm{Zn}^{2+}$-dependent metalloproteins except class III which use nicotinamide adenine dinucleotide $\left(\mathrm{NAD}^{+}\right)$as a cofactor in the deacetylation process $[3,4]$. The development of new drugs acting as inhibitors of the HDAC enzymatic activities (HDAC inhibitor, HDACi) is a proven

*Address correspondence to this author at the Laboratory of Radiopharmaceutical Research, KU Leuven, Leuven, Belgium; Tel: +32 16 330447; E-mail: guy.bormans@kuleuven.be

${ }^{\dagger}$ These authors contributed equally for this work strategy for many diseases, such as central nervous system disorders, cardiac diseases and different forms of cancer [5-8].

Prototypical $\mathrm{Zn}^{2+}$-dependent HDACi consist of 1) a capping group, also called surface recognition domain, usually a hydrophobic and aromatic group allowing the interaction with the rim of the binding pocket which occludes the entrance of the active site pocket, 2) a linker region with linear or cyclic structure, in which the $\pi-\pi$ stacking with aromatic amino acids from HDAC is important for increased affinity, 3) a $\mathrm{Zn}^{2+}$-chelating group and optionally 4) an internal cavity binding domain. Numerous natural and synthetic HDACi have been identified in recent decades [9]. These inhibitors are classified according to their structure into five categories: short-chain fatty acids, hydroxamic acids, cyclic peptides, benzamides and macrocycles. Other compounds, such as polyketides, ortho-anilides, chalcones, tropolones and sulfur containing compounds also display HDAC inhibitory activity $[10,11]$. 
So far there are four US Food and Drug Administration (FDA)-approved HDACi in clinics for cancer therapy. In 2006, suberoylanilide hydroxamic acid (SAHA, Vorinostat, Zolinza $^{\circledR}$; compound 5, Fig. 1) was approved as a first in class hydroxamic acid-based HDACi for the treatment of cutaneous T-cell lymphoma (CTCL). In 2009, the class Ispecific HDACi romidepsin (FK228, Istodax $^{\mathbb{B}}$ ), a thiol-based depsipeptide, also gained approval for the treatment of CTCL. In 2011, romidepsin was also approved for the treatment of patients suffering from peripheral T-cell lymphoma (PTCL) who have received at least one prior therapy. Two additional hydroxamic acid-based pan-HDACi, PXD101 (Belinostat, Beleodaq ${ }^{\circledR}$ ) and LBH-589 (Panobinostat, Farydak) were approved in 2014 and 2015, respectively. PXD101 received approval for refractory or relapsed PTCL and LBH589 was approved for patients with multiple myeloma who received at least two prior regimens including an immunomodulatory agent and the proteasome inhibitor bortezomib [12].

Noteworthy, many of these inhibitors are pan-HDACi thus can cause toxic side effects [6]. Increasing evidence suggest that these side effects could be limited by targeting only a limited number or ideally only one HDAC-isoform, involved in a specific disease or disease subtype, providing ultimately therapeutic tools for personalized treatments [13$16]$.

In this context, the search for selective HDACi is an ongoing hot topic. A major HDAC-isoform that is involved in various diseases is HDAC2, which is an important factor in cell development, cytokine signaling involved in immune responses and is often significantly overexpressed in cancer like acute myeloid leukemia [6] and gastric [17] and colon cancer [18-20]. In addition, HDAC2 is part of various corepressor complexes with $\mathrm{HDAC} 1$ and 3 often aberrantly recruited by oncogenic fusion proteins [21]. It also controls pro-apoptotic factor $\mathrm{p} 53$, [22] regulates memory formation and synaptic plasticity, [23] and is involved in maintenance of cardiac hypertrophic response [24], thus making HDAC2 a valuable target in the search of cures for these pathologies.

\subsection{HDAC Enzyme Activity Inhibition Values from the Literature}

Compound 2 (Fig. 1) was first reported by Rajagopal and coworkers, [25] who showed that it had a pan-HDAC IC $_{50}$ value of $1.1 \mathrm{nM}$. Subsequently Hooker and coworkers modified compound $\mathbf{1}$ by adding an additional $N$-methyl group to form compound $\mathbf{1}$ (martinostat, Fig. 1), as a positron emission tomography (PET) tracer for imaging HDACs [26, 27]. Compound 1 was found to inhibit HDAC2 $\left(\mathrm{IC}_{50}\right.$ of 2.0 $\mathrm{nM}$ ) but lacks isoform-selectivity but may be a good lead for the development of a HDAC2-selective inhibitor.

Pavlik et al. recently reported the selective and potent HDAC2 inhibitor santacruzamate A, (compound 6, Fig. 1), with an $\mathrm{IC}_{50}$ value of $119 \mathrm{pM}$ for HDAC2 [28]. Moreover in the same article santacruzamate A-SAHA hybrid 7 (Fig. 1) was described to have good inhibitory activity towards $\mathrm{HDAC} 2$ with an $\mathrm{IC}_{50}$ of $3.5 \mathrm{nM}$.

The synthetic products (santacruzamate A (6) and the hybrid 7) as well as the natural product (isolated from a cyanobacterium) santacruzamate A (6) were evaluated for isozyme-selective inhibition of HDAC2 and HDAC4, which are class I and class IIa HDAC, respectively. It was reported that all the three compounds selectively inhibited HDAC2 with relatively little inhibition of HDAC4. In contrast at 1 $\mu \mathrm{M}$, SAHA completely inhibited both class I and II HDACs. On this basis, $\mathrm{IC}_{50}$ values were determined using HDAC2, HDAC4 and HDAC6. Against HDAC2, SAHA showed an $\mathrm{IC}_{50}$ of $86 \mathrm{nM}$, whereas it was reported that the natural and synthetic santacruzamate $\mathrm{A}$ compounds have picomolar $\mathrm{IC}_{50}$ values (Table 1). However, all three compounds showed $\mathrm{IC}_{50}$ values $>1 \mu \mathrm{M}$ against HDAC4. $\mathrm{IC}_{50}$ values obtained with the natural and synthetic santacruzamate A (were identical) and

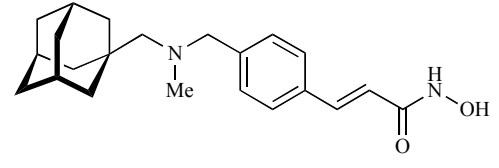

Martinostat (1)

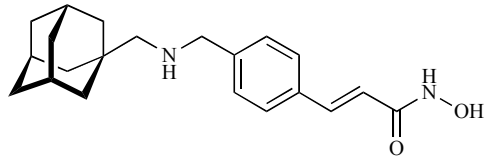

$N$-desmethyl-Martinostat (2)

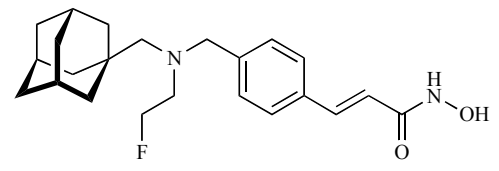

Fluoroethyl-Martinostat (3)<smiles>COc1ccc(-c2ccccc2O)cc1</smiles>

(4)

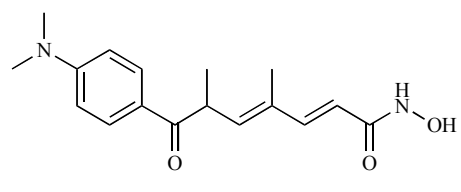

TSA (8)<smiles>O=C(CCCCCCC(=O)Nc1ccccc1)Nc1ccccc1</smiles>

SAHA (5)<smiles>CCOC(=O)NCCCC(=O)NCCc1ccccc1</smiles>

Santacruzamate A (6)

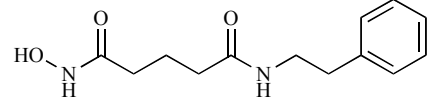

Santacruzamate A-SAHA hybrid (7)

Fig. (1). Structures of potent HDAC inhibitors investigated in this study. 
Table 1. Comparison of HDAC activities of compounds 1-10.

\begin{tabular}{|c|c|c|c|c|c|c|}
\hline \multirow[b]{2}{*}{ Compound } & \multicolumn{2}{|c|}{ Literature } & \multicolumn{2}{|c|}{$\begin{array}{c}\text { In Silico } \\
\text { Docking Studies }\end{array}$} & \multicolumn{2}{|c|}{$\begin{array}{c}\text { In Vitro } \\
\text { Present Study }\end{array}$} \\
\hline & $\begin{array}{c}\text { HDAC2 } \\
\mathrm{IC}_{50}(\mathrm{nM})\end{array}$ & $\begin{array}{c}\text { Pan-HDAC } \\
\mathrm{IC}_{50}(\mathrm{nM})\end{array}$ & $\begin{array}{c}\text { Binding Energy } \\
\text { kcal } / \mathbf{m o l}\end{array}$ & $\begin{array}{l}\text { Binding Affinity } \\
\text { HDAC2 (nM) }\end{array}$ & $\begin{array}{c}\text { HDAC2 } \\
\text { IC }_{50}(\mathrm{nM})\end{array}$ & $\begin{array}{c}\text { Pan-HDAC } \\
\mathrm{IC}_{50}(\mathrm{nM})\end{array}$ \\
\hline 1 & $2.0^{26}$ & ND & -10.59 & 17.27 & 19.41 & 0.87 \\
\hline 2 & N.D. & $1.1^{25}$ & -11.77 & 2.36 & 4.78 & 1.08 \\
\hline 3 & $651^{27}$ & - & -8.95 & 275.30 & 161 & 45.1 \\
\hline 4 & $0.81 *^{30}$ & ND & -7.35 & 3990 & 87085 & 9650 \\
\hline 5 & $85.8^{28}$ & ND & -7.92 & 1570 & $84.1(290)^{\ddagger}$ & 59.1 \\
\hline 6 & $0.119^{28}$ & ND & -6.83 & 9810 & $\begin{array}{c}8 \% \text { inhibition at } 100 \mu \mathrm{M} \\
(20 \% \text { inhibition at } 50 \mu \mathrm{M})^{\ddagger}\end{array}$ & $\begin{array}{c}11 \% \text { inhibition at } \\
100 \mu \mathrm{M}\end{array}$ \\
\hline 7 & $3.5^{28}$ & ND & -7.34 & 4180 & 7280 & 1420 \\
\hline 8 & $1.3^{34}$ & $1.8^{35}$ & -8.23 & 929.77 & $11^{\ddagger}$ & ND \\
\hline 9 & - & - & -7.10 & 6270 & $>10,000^{*}$ & ND \\
\hline 10 & - & - & -6.25 & 26240 & $>10,000^{*}$ & ND \\
\hline
\end{tabular}

* Reported in $\mathrm{K}_{\mathrm{i}}$, inhibition constant. ${ }^{\star}$ Result from Oslo. ND-Not determined/Not available.

compound 7 for HDAC6 were found to be 434, 433 and 386 $\mathrm{nM}$ respectively, while SAHA showed limited selectivity with an $\mathrm{IC}_{50}$ of $39 \mathrm{nM}$ [28].

Ononye and coworkers reported $\alpha$-aryl substituted tropolone scaffolds as potent HDAC-selective inhibitors; in particular compound 4 was reported to have a $\mathrm{K}_{\mathrm{i}}$ of $0.81 \mathrm{nM}$ $[29,30]$. These tropolone derivatives are believed to form a strong bond with the catalytic $\mathrm{Zn}^{2+}$ ion via the $\alpha$-hydroxy ketone group of the tropolone and besides high affinities for HDAC2 they were also reported to exhibit cytotoxicity in cancer cells.

During the course of our investigation, Liu Wen and coworkers reported a biological study performed on santacruzamate A 6 as well as its analogues and they observed that santacruzamate A 6 did not show any inhibition of HDAC2 even at a concentration of $2 \mu \mathrm{M}$ [31]. We recently started an investigation in search of isozymespecific HDAC2 inhibitors for potential use as cancer drugs and also for the use of these compounds as possible PET tracers for the in vivo imaging of HDAC2. In this context, we report some preliminary results of compounds 1-10 on their pan-HDAC, HDAC2 inhibition assays and in silico studies.

\section{RESULTS AND DISCUSSION}

\subsection{Chemistry}

We selected some of the literature reported compounds (Fig. 1) and synthesized compounds 1, 2, 3, 4, 6 and 7 according to reported literature procedures [25-30], whereas compounds 5 and $\mathbf{8}$ were obtained commercially. Two new fluorinated bioisosteres of santacruzamate A, (compounds 9 and 10) were synthesized. The martinostat analogue compound 3 was obtained by introduction of a 2-fluoroethyl group
(FEt) in 2 using FEtBr in DMF and with $\mathrm{K}_{2} \mathrm{CO}_{3}$ as base (See Experimental section and Supporting Information for complete characterization of all the final compounds).

For the preparation of santacruzamate A analog $\mathbf{1 0}$, $\gamma$-aminobutyric acid 11 (GABA) was first selectively converted to the $N$-ethoxycarbonyl derivative 12a with ethyl chloroformate in aqueous potassium carbonate solution (Scheme 1) [28]. Then carbamate 12a was reacted with 3fluoro-phenethylamine using EDC-HCl/TEA system in the presence of catalytic amount of DMAP in dichloromethane.

Similarly, FEt-santacruzamate A 9 was synthesized from GABA 11 in a four-step synthesis (Scheme 1). Boc protection of the 4-amino group was performed by reaction of di-tertbutyl dicarbonate $\left(\mathrm{Boc}_{2} \mathrm{O}\right)$ in $1 \mathrm{M} \mathrm{NaOH}-\mathrm{THF}$ mixture to form 12b, which was further reacted with phenethylamine using $\mathrm{EDC}-\mathrm{HCl}$ in the presence of catalytic amounts of DMAP in dichloromethane and followed by boc-deprotection with TFA yielding 4-amino- $N$-phenethyl-butyramid 13. FEtsantacruzamate A 9 was prepared from 13 by transcarboxylation, using DBU- $\mathrm{CO}_{2}$ zwitterionic complex [32], and subsequent $O$-alkylation with 2-bromofluoroethane. The synthesized compounds were characterized by ${ }^{1} \mathrm{H}-,{ }^{13} \mathrm{C}$ - and ${ }^{19}$ F-NMR spectra and by ESI-MS. The incorporation of the carboxylate group and the exact position of the 2fluoroethyl-group were demonstrated using 2D-NMR $\left({ }^{1} \mathrm{H}\right.$ ${ }^{1} \mathrm{H}-\mathrm{COSY}$ and $\left.{ }^{1} \mathrm{H}-{ }^{13} \mathrm{C} \mathrm{HMBC}\right)$ experiments. ${ }^{1} \mathrm{H}-{ }^{1} \mathrm{H}-\mathrm{COSY}$ and ${ }^{1} \mathrm{H}_{-}{ }^{13} \mathrm{C}$ HBMC correlations for FEt-santacruzamate A 9 are listed in Table S1-A and Table S1-B (Supplementary Information, pp. 4-5).

Further in an attempt to radiosynthesis of the ${ }^{18} \mathrm{~F}$-labeled analogue of santacruzamate-A $\left(\left[{ }^{18} \mathrm{~F}\right] 10\right)$, new nickel complexes 15 and 16 were prepared from 3-bromophenethylsantacruzamate A (14) by adaptation of a recently described 
A<smiles>CCOC(=O)NCCCC(=O)NCCc1cccc(F)c1</smiles>

B<smiles>CCOC(=O)NCCCC(N)=O</smiles><smiles>CN(c1ccccc1-c1ccccn1)S(=O)(=O)c1ccccc1[N+](=O)[O-]</smiles>

17<smiles>CCOC(=O)NCCCC(=O)NCCc1cccc(Br)c1</smiles>

$$
[
$$

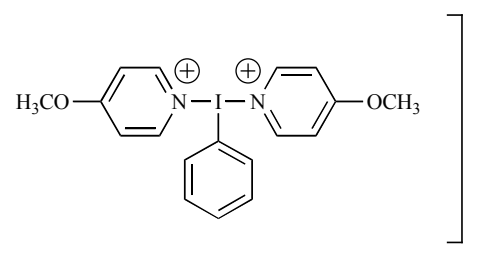

$(\mathrm{TfO})_{2} 2 \ominus$<smiles></smiles>

18

Scheme 1. Synthesis of fluorinated analogues of Santacruzamate-A. Reagents and conditions: (i) ethyl chloroformate, $\mathrm{K}_{2} \mathrm{CO}_{3}, \mathrm{H}_{2} \mathrm{O}, 0{ }^{\circ} \mathrm{C}$ for 2h then $16 \mathrm{~h}$, RT; (ii) $\mathrm{Boc}_{2} \mathrm{O}, 1 \mathrm{M} \mathrm{NaOH}$, THF, 24h, RT; (iii) 3-fluorophenethylamine, $\mathrm{Et}_{3} \mathrm{~N}, \mathrm{CH}_{2} \mathrm{Cl}_{2}, \mathrm{DMAP}, \mathrm{EDC} \mathrm{HCl}, 0{ }^{\circ} \mathrm{C}$ for $1 \mathrm{~h}$ then overnight RT; (iv) TFA; (v) phenethylamine, $\mathrm{Et}_{3} \mathrm{~N}, \mathrm{CH}_{2} \mathrm{Cl}_{2}$, DMAP, EDC HCl, $0{ }^{\circ} \mathrm{C}$ for $1 \mathrm{~h}$ then $16 \mathrm{~h}$, RT; (vi): (1) DBU-CO 2 complex, acetonitrile, $1.5 \mathrm{~h}, 0-5{ }^{\circ} \mathrm{C}$, (2) $\mathrm{BrCH}_{2} \mathrm{CH}_{2} \mathrm{~F}$, overnight RT. [B] Synthesis of the nickel aryl complex precursor for the radiosynthesis of ${ }^{18} \mathrm{~F}$ labeled analogue of santacruzamate-A. Reagents and conditions: (i) 3-bromophenethylamine, $\mathrm{Et}_{3} \mathrm{~N}_{,} \mathrm{CH}_{2} \mathrm{Cl}_{2}, \mathrm{DMAP}, \mathrm{EDC} \mathrm{HCl}, 0{ }^{\circ} \mathrm{C}$ for $1 \mathrm{~h}$ then overnight RT; (ii) tetramethylendiamine, Ni(COD) $)_{2}$, toluene, RT, 6h; (iii): [2-(2-piridinyl)phenyl-2-nitrobenzenesulfonamid]silver(I) (17), pyridine, toluene, acetonitrile, RT, $1 \mathrm{~min}$; (iv): ${ }^{18} \mathrm{~F}^{-}$, hypervalent iodine oxidant 18 , acetonitrile.

method of Lee et al. [33]. The oxidative $\left[{ }^{18} \mathrm{~F}\right]$ fluorination was performed using $40 \mu \mathrm{L}$ of ${ }^{18} \mathrm{~F}$-fluoride in water $(170$ $\mathrm{MBq}$ ), and was added to $4 \mathrm{ml} \mathrm{MeCN}$ containing $20 \mathrm{mg} 18$ crown-6, the reagents were mixed well to form ${ }^{18} \mathrm{~F}$ stock solution. Three experiments were attempted using 1, 2 and 3 mg precursor (16) and 1 equivalent of PIBMP (18). To each reaction vial containing precursor (16), was added $400 \mathrm{uL}$ of ${ }^{18} \mathrm{~F}$ stock solution under a rubber septum. Reactions were run for $1 \mathrm{~min}$ at room temperature and a color change was observed (to yellow and reddish brown for higher amounts of precursors). However, this initial radiosynthetic attempt for oxidative $\left[{ }^{18} \mathrm{~F}\right]$ fluorination was unsuccessful as no product was observed either with HPLC or with iTLC. However, radiosynthesis of $\left[{ }^{11} \mathrm{C}\right] \mathbf{1}$ had successfully started from precursor 2 , we used a procedure as previously reported by Hooker and coworkers. And a detailed study on $\left[{ }^{11} \mathrm{C}\right] \mathbf{1}$ will be published in a due course.

\subsection{Pan-HDAC and HDAC2 Inhibition Assays}

Assays were carried out in two different labs in Luxembourg and Oslo, Norway in order to strengthen the confidence of the results. Different assays conditions were used to verify the results. HDAC enzymes were isolated from K562 cell extracts to measure total HDAC activity as previously described [36, 37]. HDAC fluorogenic assay kits from BPS Bioscience or Active Motif were used to measure HDAC2 activity (See Materials and Methods, Sections 6.1 and 6.2 for details).

Compounds 1 and 2 showed HDAC2 IC $_{50}$ values of 19.4 and $4.8 \mathrm{nM}$, respectively (Table 1). Both showed a significantly lower pan-HDAC $\mathrm{IC}_{50}$ of 0.87 and $1.08 \mathrm{nM}$, respectively. The fluoroethyl analogue of martinostat 3 was found to be less effective than compound $\mathbf{1}$ and $\mathbf{2}$ with a HDAC2 IC $_{50}$ value of $161 \mathrm{nM}$, and also showed a lower pan- 
HDAC IC $_{50} 45.1 \mathrm{nM}$. Compound 4 which carries a tropolone moiety showed an HDAC2 $\mathrm{IC}_{50}$ value of $87 \mu \mathrm{M}$, although it was reported to have a $\mathrm{K}_{\mathrm{i}}$ value of $0.81 \mathrm{nM}$ against HDAC2 [31]. Compound 5 (SAHA) showed an $\mathrm{IC}_{50}$ value of 84 and $59 \mathrm{nM}$ for HDAC2 and pan-HDAC respectively.

The inhibitory activity of compounds 6 and 7 was also found to be far less than reported in the literature $\left(\mathrm{IC}_{50}\right.$ of 0.119 and $3.5 \mathrm{nM}$, respectively) [28] for HDAC2. Even at a concentration of $100 \mu \mathrm{M} 6$ was not able to completely block neither total HDAC nor HDAC2 activity. Compound 7 showed an $\mathrm{IC}_{50}$ value of $7.28 \mu \mathrm{M}$ and $1.42 \mu \mathrm{M}$ for HDAC2 and pan-HDAC respectively (Table $\mathbf{1}$ ).

Further, we choose compound $\mathbf{6}$ to study concentrationresponse in detail, with compounds $\mathbf{5}$ and $\mathbf{8}$ as standards (Fig. 2). We did not observe any effect of $\mathbf{6}$ under normal assay conditions (manufacturer's protocol), whereas $\mathbf{5}$ and $\mathbf{8}$ showed HDAC2 inhibition in agreement with literature values (Fig. 2). Since the observed absence of inhibitory activity for $\mathbf{6}$ was unexpected, we ran several control experiments. Assays were run against HDAC2 where $\mathbf{6}$ was used in combination with either $\mathbf{5}$ or $\mathbf{8}$ (data not shown), in order to verify if some of $\mathbf{6}$ or its impurities (if present) would interfere with the assay. We found that the decrease in activity was solely caused by either $\mathbf{5}$ or $\mathbf{8}$ and the contribution of $\mathbf{6}$ was negligible.

Since santacruzamate A $\mathbf{6}$ was reported as a potent HDAC2 inhibitor, [28] sparked our interest on this molecule for use as a potential radiolabeled probe. Subsequently we could achieve the synthesis of two bioisosteres of santacruzamate A $\mathbf{9}$ and $\mathbf{1 0}$, and these compounds were tested in HDAC assays. An assay against HDAC2 for two fluorine derivatives $\mathbf{9}$ and $\mathbf{1 0}$ produced no decrease in activity even at a concentration of $10 \mu \mathrm{M}$ (Table 1). Equally no inhibitory effect was observed for other class I HDACs (HDAC1 and 3) (data not shown).

We further investigated whether assay conditions could explain the lack of activity of santacruzamate A $\mathbf{6}$. As shown in Fig. 3, compound $\mathbf{6}$ was tested against recombinant HDAC2 enzymes under different assay conditions (HDAC fluorogenic assay from Active Motif vs BPS Bioscience).

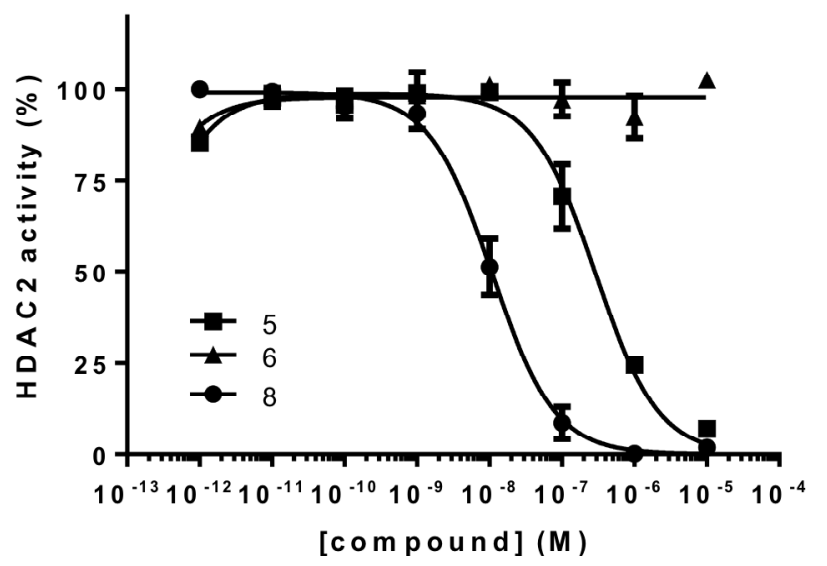

Fig. (2). Activity-concentration curves of compound 5, 6 and 8 using fluorogenic HDAC2 assay (BPS Bioscience, manufacturer's conditions).

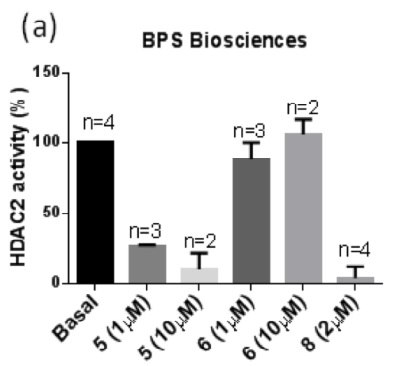

(b) Active Motif assay (BPS enzyme)
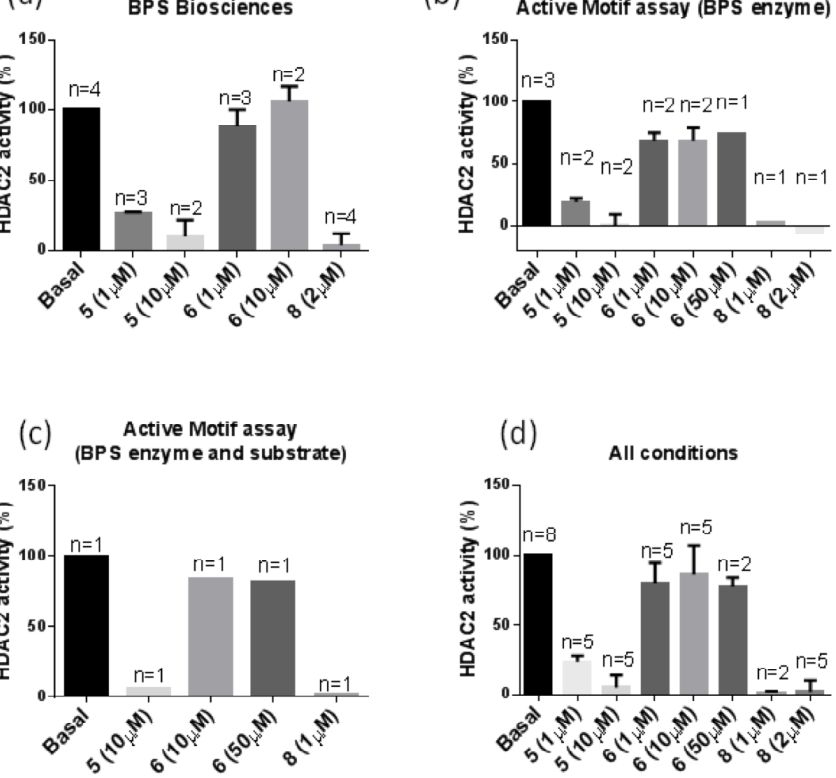

Fig. (3). HDAC2 activity of 5, 6 and $\mathbf{8}$ under different assay conditions. (a) BPS Bioscience following the manufacturer's protocol. (b) Active Motif assay following the manufacturer's protocol in the presence of HDAC2 enzyme from BPS Bioscience. (c) Active Motif assay with the enzyme and substrate $(20 \mu \mathrm{M})$ from BPS Bioscience. (d) Results from (a)-(c) merged.

However, none of these assay conditions could reproduce the subnanomolar affinity reported by Pavlik et al., [28] thus different assay conditions could not explain the lack of effect of $\mathbf{6}$ on HDAC2 activity that we observed.

Our results for the compounds, 4, 6 and 7 indicate marked inconsistencies with the results published by Ononye et al. and Pavlik et al., and those results should be reconsidered and looked at with caution [28-30].

\section{MOLECULAR DOCKING STUDY}

To further investigate the interactions of these compounds with the HDAC2 enzyme binding pocket and to predict the in silico binding energy and binding affinity predictions we used molecular docking studies. Rational drug design involves investigating new molecules that complement their biological target in shape and charge, and bind to the active site effectively [38]. Molecular docking is an in silico modeling method which attempts to predict noncovalent interactions usually between a macromolecule and a small molecule, and is a widely used computational tool both in academia and industry for rapid identification of potential drugs with minimal expense and effort [39].

We performed docking studies using Autodock 4.2.6 in a Cygwin Linux environment. Following ligand and target preparation in Autodock Tools 1.5.6, the energy minimized compounds were docked into the binding pocket in HDAC2 crystal structure [40]. The HDAC2 crystal structure used in the docking studies was obtained from the RCSB Protein Data Bank (PDB ID: 4lxz). For the receptor preparation, water molecules were removed, polar hydrogen atoms were 

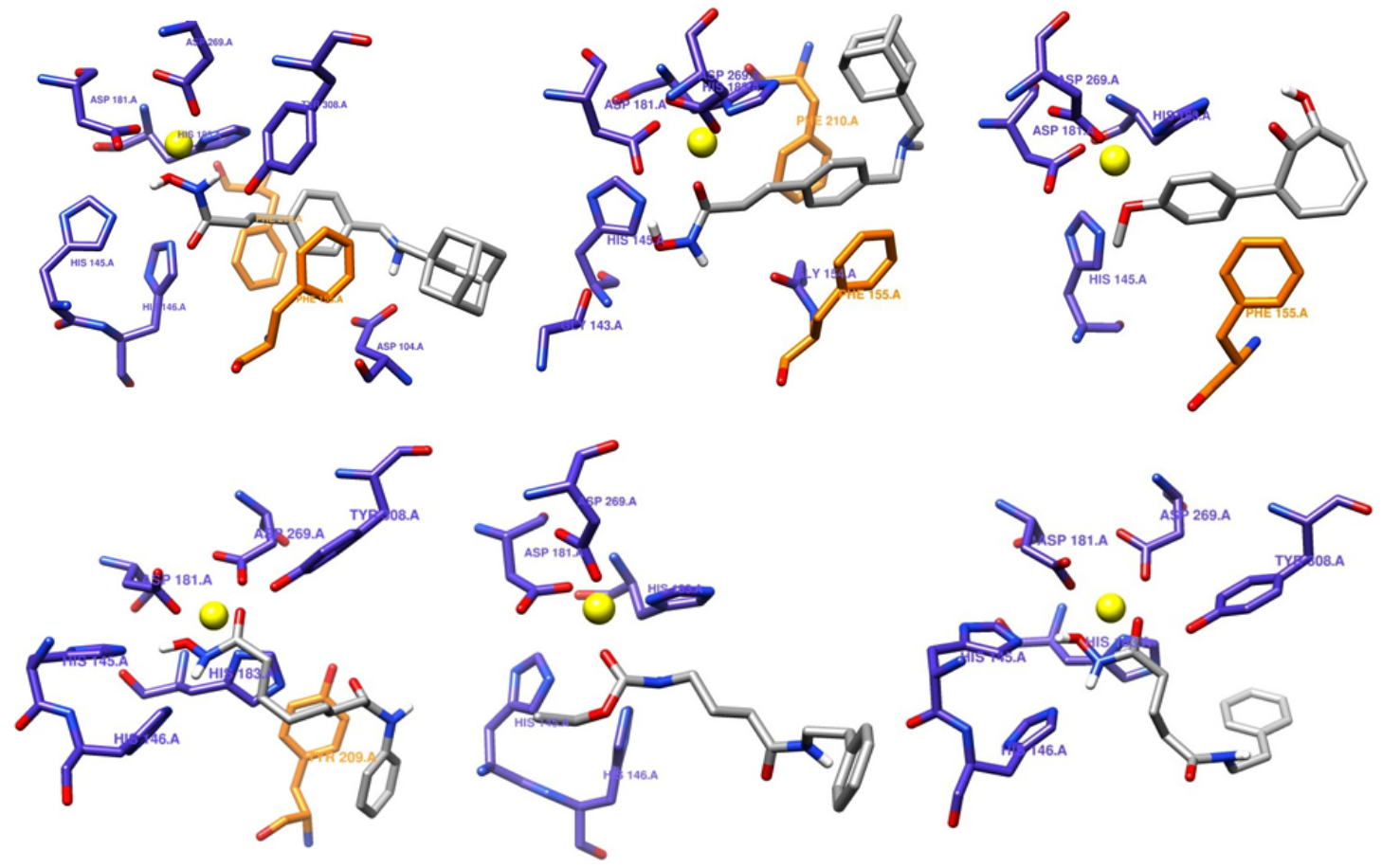

Scheme 2. 3D representation of predicted binding models of 2, 1, 4 (top row, left to right) and 5, 6, 7 (bottom row, left to right) respectively in the binding pocket of HDAC2. Key Interactions between the protein residues (blue) and the ligand (grey) are shown and the zinc ion is shown as a yellow sphere (rest of the protein residues omitted for clarity). Residues shown in orange are involved in $\pi-\pi$ stacking.

added, and Kollman united atom partial charges were assigned to HDAC2 using Autodock Tools at a pH of 7.4. For the ligand preparation, the 3D structure was generated with the use of ChemBioOffice Version 11.0 and the $\mathrm{mm} 2$ energy of the molecule was minimized to minimum RMS Gradient of 0.050 for each ligand. To understand the importance of $\mathrm{Zn}^{2+}$ binding site in HDAC2, docking was performed by setting the grid box size at 60x60x60 units of $0.375 \AA$ spacing along the $x, y$, and $z$ axes, and centered on atom ZN401. Cygwin Terminal was used to run AutoGrid to generate the grid map of the various ligand and receptor atoms. After the grid map was generated, the Lamarckian genetic algorithm (LGA) implemented in AutoDock was applied to estimate the possible conformations of the ligandprotein complex. AutoDock simulations were performed 50 times to be sure to cover all possible binding possibilities. The result with the lowest docking energy analysis in cluster rank 1 was used for further analysis. For visualization of the docked conformations, Chimera 1.10.1 software package was used.

Our docking study indicated martinostat derivatives 1-3 fit well in the binding pocket and showed calculated HDAC2 binding affinity values of 17.3, 2.4, and $275 \mathrm{nM}$, respectively. Also these three compounds can chelate $\mathrm{Zn}^{2+}$, with measured distance of $1(\mathrm{O}-\mathrm{H}),(\mathrm{C}=\mathrm{O}), 2$ and $\mathbf{3}(\mathrm{C}=\mathrm{O})$ from $\mathrm{Zn}^{2+}$ being $1.72,1.78$ and $1.75 \AA$, respectively. Additionally, all three compounds showed two $\pi-\pi$ interactions with Phe155A and Phe210A, which attributes to the favorable interaction with HDAC2. A similar $\pi-\pi$ stacking interaction was also observed for chidamide with Phe155A and Phe210A in the binding pocket of HDAC2 [41] Besides key hydrogen bonding contacts, compound 2 also exhibited an additional hydrogen bond contact with Asp104. The key interactions in the catalytic pocket are with His183, Asp181, Asp269 and Tyr308, as well as compound 2 additionally forming a key hydrogen bond with Asp104. (See Table S2, Supporting Information for more details)

Further for compound $\mathbf{4}$, an in silico binding affinity value of $3.99 \mu \mathrm{M}$ was obtained, and the methoxy group was observed to interact with $\mathrm{Zn}^{2+}$ ion $(1.90 \AA)$ instead of the anticipated hydroxyl ketone moiety. Compound $\mathbf{4}$ makes one $\pi-\pi$ interaction with Phe155A and only one hydrogen bonding contact with His145A in the binding pocket, explaining its low binding affinity. For compounds 6 and 7, an in silico binding affinity value of 9.8 and $4.2 \mu \mathrm{M}$ was obtained and no $\pi-\pi$ contacts were observed as anticipated. The lower binding energy for $\mathbf{6}$ and $\mathbf{7}$ in these simulation studies could be because of lack of any $\pi-\pi$ interactions. Similarly compounds $\mathbf{9}$ and $\mathbf{1 0}$ showed an in silico binding affinity value of 6.3 and $26.2 \mu \mathrm{M}$, respectively. Although in silico results have to be read with caution due to their inconsistencies, our in vitro assays for compounds $\mathbf{1}-\mathbf{4 , 6}$, 7, 9 and 10 generally agree with our in silico simulation studies.

\section{CONCLUSION}

In summary we have studied selected potent HDAC inhibitors for their HDAC2 and pan HDAC inhibitory activity in order to identify potential HDAC2 PET tracers. We observed that the $\mathrm{IC}_{50}$ values of compounds $\mathbf{1 ,}, \mathbf{3}, \mathbf{5}$ and $\mathbf{8}$ are in agreement with literature values. However, we have found major differences in the $\mathrm{IC}_{50}$ values for the $\alpha$-aryl tropolone 4, santacruzamate A 6 and santacruzamate A- 
SAHA hybrid 7 against the literature reports. We further carefully, i) studied the inhibitory effect of santacruzamate A 6 by using different assay conditions and different concentrations against control compounds $\mathbf{5}$ and $\mathbf{8}$, but we could not reproduce the literature affinity values and ii) performed molecular docking studies, which were also in agreement with our in vitro assay results, additionally the docking studies showed the key interactions of the potent compounds (example, $\mathbf{1}$ and 2) in HDAC2 binding pocket, while compounds 4,6 and 7 did not show key $\pi-\pi$ interactions and additional hydrogen bonding to contribute to higher affinity. Our results suggest that the presence of an aryl group for a $\pi-\pi$ interaction, a hydrogen bond donor and an appropriate bulky cap group can be helpful for achieving selectivity when designing new HDAC2 inhibitors. In line with santacruzamate A $\mathbf{6}$ results, fluorinated bioisosteres of santacruzamate A, 9 and $\mathbf{1 0}$ did not show any HDAC2 inhibition even at $10 \mu \mathrm{M}$ concentration. Further, literature inhibitory activity for compounds $\mathbf{4 , 6}$ and 7 has to be read with caution and hope these results will be useful for other researchers working with these compounds in the area of epigenetics.

\section{MATERIAL AND METHODS}

\subsection{Cell Culture, Total Protein Extraction and in vitro HDAC Activity Assays (Luxembourg)}

Chronic myeloid leukemia K-562 cells (American Type Culture Collection, Manassas, USA) were cultured in RPMI 1640 (BioWhittaker ${ }^{\circledR}$, Lonza, Verviers, Belgium) supplemented with $10 \%$ heat-inactivated fetal calf serum (BioWhittaker ${ }^{\mathbb{R}}$ ) and $1 \%$ antibiotic-antimycotic (Bio Whittaker ${ }^{\circledR}$ ) at $37^{\circ} \mathrm{C}$ in humid atmosphere and $5 \% \mathrm{CO}_{2}$. Cells were harvested, washed in cold PBS $1 \mathrm{x}$, and lysed in MPER $^{\circledR}$ (Thermo-scientific, Erembodegem-Aalst, Belgium) supplemented by $1 \mathrm{x}$ protease inhibitor cocktail (Complete EDTA-free, Roche, Prophac, Luxembourg, Luxembourg) according to manufacturer's instructions. HDAC activity assays were carried out as previously described [36]. For total HDAC activity assay, we used $10 \mu \mathrm{g}$ of K-562 total protein extracts. The quantity of enzymes per well, concentration of substrates and cofactor, and incubation times were used as previously reported [37]. $\mathrm{IC}_{50}$ values were determined using the GraphPad Prism 6.0 software.

\subsection{Fluorogenic HDAC2 Assay (Oslo)}

HDAC2 activity in the presence of the different inhibitors was measured by using HDAC fluorogenic assay kits from BPS Bioscience, (CA, USA) or Active Motif (CA, USA). The HDAC2 enzyme was obtained from BPS Bioscience (concentration as recommended by producer (BPS Bioscience) or $56 \mathrm{ng} /$ reaction (using assay from Active Motif)).

\subsection{Experimental Section}

\section{(E)-3-(4)(((3R,5R,7R)-Adamantan-1-ylmethyl)(methyl)} amino)methyl)-phenyl)-N-hydroxy acrylamide [1, Martinostat]

Colorless Powder, ${ }^{1} \mathrm{H}$ NMR (CD $\left.{ }_{3} \mathrm{OD}\right): \delta 1.46$ (brs, 6H, $\mathrm{CH}_{2}$ ), 1.56-1.68 (m, 6H, $\mathrm{CH}_{2}$ ), 1.85 (brs, 3H), 2.03 (brs, $2 \mathrm{H}$ ), $2.13(\mathrm{~s}, 3 \mathrm{H}, \mathrm{Me}), 3.46\left(\mathrm{~s}, 2 \mathrm{H}, \mathrm{CH}_{2}\right), 6.38(\mathrm{~d}, J=15.8 \mathrm{~Hz}$, $1 \mathrm{H}, \mathrm{CH}), 7.24-7.48$ (m, 5H, Ar). ${ }^{13} \mathrm{C}$ NMR (CD $\left.3 \mathrm{OD}\right): \delta 30.1$ (3C), 36.3, 38.4 (3C), 42.4 (3C), 46.4, 66.0, 72.1, 118.3, 128.7 (2C), 130.6 (2C), 135.1, 141.1, 143.61, 166.5. HRMS (ESI) Calcd. for $\mathrm{C}_{22} \mathrm{H}_{31} \mathrm{~N}_{2} \mathrm{O}_{2}[\mathrm{M}+\mathrm{H}]^{+}:$355.2380. Found: 355.2390 .

\section{(E)-3-(4((((3R,5R,7R)-Adamantan-1-ylmethyl)amino)} methyl)-phenyl)-N-hydroxy Acrylamide [(2), N-DesmethylMartinostat]

Colourless Powder, ${ }^{1} \mathrm{H}$ NMR ( $\left.\mathrm{CD}_{3} \mathrm{OD}\right): \delta$ 1.58-1.77 (m, $13 \mathrm{H}), 1.98-2.02(\mathrm{~m}, 3 \mathrm{H}), 2.67\left(\mathrm{~s}, 2 \mathrm{H}, \mathrm{CH}_{2}\right), 4.25(\mathrm{~s}, 2 \mathrm{H}$, $\left.\mathrm{CH}_{2}\right), 6.54(\mathrm{~d}, J 15.7 \mathrm{~Hz}, 1 \mathrm{H}, \mathrm{CH}), 7.54-7.65$ (m, 5H, Ar). ${ }^{13} \mathrm{C}$ NMR (CD $\left.{ }_{3} \mathrm{OD}\right): \delta 29.5$ (3C), 33.4, 37.5 (3C), 40.7 (3C), 52.9, 59.9, 120.1, 129.5, 132.0, 133.6, 137.7, 140.5, 166.0. HRMS (ESI) Calcd. for $\mathrm{C}_{21} \mathrm{H}_{29} \mathrm{~N}_{2} \mathrm{O}_{2}[\mathrm{M}+\mathrm{H}]^{+}$: 341.2224 . Found: 341.2244.

(E)-3-(4((((3R,5R,7R)-Adamantan-1-ylmethyl)(2-fluoroethyl) amino)methyl)-phenyl)-N-hydroxyacrylamide [3, FluoroethylMartinostat]

Colourless Powder, ${ }^{1} \mathrm{H}$ NMR ( $\left.\mathrm{CD}_{3} \mathrm{OD}\right): \delta$ 1.55-1.68 (m, $\left.12 \mathrm{H}, \mathrm{CH} \& \mathrm{CH}_{2}\right), 1.80-1.88\left(\mathrm{~m}, 3 \mathrm{H}, \mathrm{CH} \& \mathrm{CH}_{2}\right), 2.87-2.95(\mathrm{~m}$, $\left.2 \mathrm{H}, \mathrm{CH}_{2}\right), 4.14-4.32\left(\mathrm{~m}, 2 \mathrm{H}, \mathrm{CH}_{2}\right), 4.52-4.60\left(\mathrm{~m}, 4 \mathrm{H}, 2 \mathrm{CH}_{2}\right)$, $6.37(\mathrm{~d}, 1 \mathrm{H}, J 15.2, \mathrm{CH}), 7.22-7.29$ (m, 2H, Ar), 7.42-7.49 $(\mathrm{m}, 3 \mathrm{H}, \mathrm{Ar}) .{ }^{13} \mathrm{C} \mathrm{NMR}\left(\mathrm{CD}_{3} \mathrm{OD}\right): \delta 30.0,37.0,38.1,42.3$, $54.2,60.0,60.9,66.3,82.1,83.8,118.7,128.8,129.0,129.1$, 135.5, 141.6, 166.6. HRMS (ESI) Calcd. for $\mathrm{C}_{23} \mathrm{H}_{32} \mathrm{FN}_{2} \mathrm{O}_{2}$ $[\mathrm{M}+\mathrm{H}]^{+}:$387.2442. Found: 387.2406.

\section{a-(4-Methoxyphenyl) Tropolone [4]}

Yellow Powder, ${ }^{1} \mathrm{H}$ NMR $\left(\mathrm{CDCl}_{3}\right)$ : $\delta 3.86$ (s, 3H, OMe), 6.95-7.00 (m, 2H, Ar), 7.03-7.09 (m, 1H, Ar), 7.31-7.43 (m, $2 \mathrm{H}, \mathrm{Ar}), 7.46-7.51$ (m, 2H, Ar), 7.56-7.61 (m, 1H, Ar). ${ }^{13} \mathrm{C}$ NMR $\left(\mathrm{CDCl}_{3}\right): \delta 55.5,113.9(2 \mathrm{C}), 122.1,127.5,130.9$ (2C), $132.3,136.5,138.8,140.6,159.9,170.5,171.4$. HRMS (ESI) Calcd. For $\mathrm{C}_{14} \mathrm{H}_{13} \mathrm{O}_{3}[\mathrm{M}+\mathrm{H}]^{+}: 229.0859$. Found: 229.0848 .

\section{[3-[2-(phenyl)-ethylcarbamoyl]-propyl]-carbamic Acid ethyl ester [6, Santacruzamate A]}

Colourless Powder, mp. 114-115 ${ }^{\circ} \mathrm{C}$, Lit. [28] mp. 112$113{ }^{\circ} \mathrm{C} . R_{f}[\mathrm{~A}]=0.64, R_{f}[\mathrm{~B}]=0.76 .{ }^{1} \mathrm{H}-\mathrm{NMR}\left(\mathrm{CDCl}_{3}\right) \delta$ 1.22 (t, $J=7.1 \mathrm{~Hz}, 3 \mathrm{H}, \mathrm{CH}_{3} \mathrm{CH}_{2} \mathrm{O}$ ), 1.79 (pent, $J=6.8 \mathrm{~Hz}$, $\left.2 \mathrm{H}, 3-\mathrm{CH}_{2}\right), 2.16\left(\mathrm{t}, J=7.0 \mathrm{~Hz}, 2 \mathrm{H}, 2-\mathrm{CH}_{2}\right), 2.82(\mathrm{t}, J=7.1$ $\left.\mathrm{Hz}, 2 \mathrm{H}, \mathrm{PhCH}_{2} \mathrm{CH}_{2}\right), 3.16\left(\mathrm{dd}, \mathrm{J}=6.1,12.3 \mathrm{~Hz}, 2 \mathrm{H}, 4-\mathrm{CH}_{2}\right)$, $3.51\left(\mathrm{dd}, J=7.0,13.0 \mathrm{~Hz}, 2 \mathrm{H}, \mathrm{PhCH}_{2} \mathrm{CH}_{2}\right), 4.08$ (q, $J=7.1$ $\mathrm{Hz}, 2 \mathrm{H}, \mathrm{CH}_{3} \mathrm{CH}_{2} \mathrm{O}$ ), 4.93 (br s, $1 \mathrm{H}, \mathrm{NH}$ ), 5.93 (br s, $1 \mathrm{H}$, $\mathrm{NH})$, 7.18-7.31 (m, 5H, $\left.\mathrm{PhCH}_{2} \mathrm{CH}_{2}\right) .{ }^{13} \mathrm{C}-\mathrm{NMR}\left(\mathrm{CDCl}_{3}\right) \delta$ $14.6\left(\mathrm{CH}_{3} \mathrm{CH}_{2} \mathrm{O}\right), 26.1$ (C-3), $33.6(\mathrm{C}-2), 35.6\left(\mathrm{PhCH}_{2} \mathrm{CH}_{2}\right)$, 40.1 (C-4), $40.6\left(\mathrm{PhCH}_{2} \mathrm{CH}_{2}\right), 60.8\left(\mathrm{CH}_{3} \mathrm{CH}_{2} \mathrm{O}\right), 126.4(\mathrm{Ph}-$ C4), 128.6 (Ph-C2,6), 128.7 (Ph-C3,5), 138.8 (Ph-C1), 157.1 (NHCOOEt), $172.5\left(\mathrm{CH}_{2} \mathrm{CONH}\right)$. HRMS (ESI) Calcd. For $\mathrm{C}_{15} \mathrm{H}_{23} \mathrm{~N}_{2} \mathrm{O}_{3}[\mathrm{M}+\mathrm{H}]^{+}: 279.1703$. Found: 279.1709.

\section{$N^{1}$-Hydroxy- $N^{5}$-(2-phenethyl)-pentanediamide [7, Santacruzamate-SAHA Hybrid]}

Yellow Powder, ${ }^{1} \mathrm{H}$ NMR $\left(\mathrm{CDCl}_{3}\right.$ and a drop of $\left.\mathrm{CD}_{3} \mathrm{OD}\right)$ : $\delta$ 1.82-1.86 (m, 2H, $\left.\mathrm{CH}_{2}\right), 2.03-2.06\left(\mathrm{~m}, 2 \mathrm{H}, \mathrm{CH}_{2}\right), 2.13-2.18$ $\left(\mathrm{m}, 2 \mathrm{H}, \mathrm{CH}_{2}\right), 2.79-2.84\left(\mathrm{~m}, 2 \mathrm{H}, \mathrm{CH}_{2}\right), 3.37-3.48(\mathrm{~m}, 2 \mathrm{H}$, 
$\left.\mathrm{CH}_{2}\right), 7.19-7.32$ (m, 5H, Ar). ${ }^{13} \mathrm{C}$ NMR $\left(\mathrm{CDCl}_{3}\right.$ and a drop of $\left.\mathrm{CD}_{3} \mathrm{OD}\right): \delta 22.0,32.1,35.1,35.5,40.8,126.4,128.6,128.7$, 139.0, 169.2, 173.9. HRMS (ESI) Calcd. For $\mathrm{C}_{13} \mathrm{H}_{19} \mathrm{~N}_{2} \mathrm{O}_{3}$ $[\mathrm{M}+\mathrm{H}]^{+}: 251.1390$. Found: 251.1385 .

\section{(3-Phenethylcarbamoyl-propyl)-carbamic acid 2-fluoro-} ethyl ester (9, Fluoroethyl-Santacruzamate A)

\section{Method A}

All operations were carried out in a dry reaction vessel under argon atmosphere. DBU- $\mathrm{CO}_{2}$ complex (470 mg, 2.4 mmol) was suspended in anhydrous acetonitrile $(10 \mathrm{~mL})$ and cooled to $0{ }^{\circ} \mathrm{C}$ in an ice-water bath. A solution of 4-amino$\mathrm{N}$-phenethyl-butyramide (13 free base, $412 \mathrm{mg}, 2 \mathrm{mmol})$ in anhydrous acetonitrile $(15 \mathrm{~mL})$ was added dropwise (60-70 min) with stirring. 2-fluoroethyl bromide $(380 \mathrm{mg}, 240 \mu \mathrm{L}, 3$ mmol) was added and the reaction mixture was stirred for further $24 \mathrm{~h}$ at room temperature. The clear solution was poured on to water $(30 \mathrm{~mL})$ and the resulting suspension was extracted with chloroform $(4 \mathrm{x} 50 \mathrm{~mL})$. The combined organic phase was washed with brine, dried $\left(\mathrm{Na}_{2} \mathrm{SO}_{4}\right)$ and concentrated under reduced pressure. The crude product was purified by column chromatography on silica gel (80 g Kieselgel, eluent: ethylacetate-chloroform 7:3 (v/v), $50 \mathrm{~mL}$ fractions). Yield: $172 \mathrm{mg}$ (30\%).

\section{Method B}

To a solution of 4-amino- $N$-phenethyl-butyramide (13) free base (412 mg, $2 \mathrm{mmol}, 1$ eq.) in anhydrous $\mathrm{N}, \mathrm{N}$ dimethylformamide $(40 \mathrm{~mL})$ was added $\mathrm{Cs}_{2} \mathrm{CO}_{3}(1.95 \mathrm{~g}$, 6 mmol, 3 eq.) and tetrabutylammonium trifuoromethansulfonate (2.35 g, $6 \mathrm{mmol}, 3$ eq.). Carbon dioxide gas (20 $\mathrm{mL} / \mathrm{min}$ ) was bubbled through the suspension for $60 \mathrm{~min}$ at room temperature. Thereafter, 2-fluoroethyl-bromide (760 $\mathrm{mg}, 480 \mu \mathrm{L}, 6 \mathrm{mmol}$ ) was added and the reaction mixture was stirred for further $24 \mathrm{~h}$ at room temperature. The solvent was removed under reduced pressure. Water $(30 \mathrm{~mL})$ was added to the residue and the suspension was extracted with chloroform (4 x $50 \mathrm{~mL})$. The combined organic layer was washed with brine $(20 \mathrm{~mL})$ and dried $\left(\mathrm{Na}_{2} \mathrm{SO}_{4}\right)$. The solvent was removed in vacuum and the residue was purified by column chromatography on silica gel as described above. Yield: $390 \mathrm{mg}(65 \%)$. mp. $98-99{ }^{\circ} \mathrm{C} . R_{f}[\mathrm{C}]=0.27, R_{f}[\mathrm{D}]=$ $0.47, R_{f}[\mathrm{E}]=0.24 .{ }^{1} \mathrm{H}-\mathrm{NMR}\left(\mathrm{CDCl}_{3}\right) \delta 1.80$ (pent, $J=6.9$ $\left.\mathrm{Hz}, 2 \mathrm{H}, 3-\mathrm{CH}_{2}\right), 2.17\left(\mathrm{t}, J=7.0 \mathrm{~Hz}, 2-\mathrm{CH}_{2}\right), 2.81(\mathrm{t}, J=7.0$ $\mathrm{Hz}, 2 \mathrm{H}, \mathrm{PhCH}_{2} \mathrm{CH}_{2}$ ), 3.18 (q, $\left.\mathrm{J}=6.4 \mathrm{~Hz}, 2 \mathrm{H}, 4-\mathrm{CH}_{2}\right), 3.51$ (dd, $\left.J=7.0 \mathrm{~Hz}, 13.0 \mathrm{~Hz}, 2 \mathrm{H}, \mathrm{PhCH}_{2} \mathrm{CH}_{2}\right), 4.21-4.31(\mathrm{~m}, 2 \mathrm{H}$, $\mathrm{CH}_{2} \mathrm{CH}_{2} \mathrm{~F}$ ), 4.50-4.61 (m, $\left.2 \mathrm{H}, \mathrm{CH}_{2} \mathrm{CH}_{2} \mathrm{~F}\right), 5.21$ (br s, $1 \mathrm{H}$, $\mathrm{FCH}_{2} \mathrm{CH}_{2} \mathrm{OCONHCH}_{2}$ ), 5.89 (br s, $1 \mathrm{H}, \mathrm{CONHCH}_{2}$ ), 7.17$7.31\left(\mathrm{~m}, 5 \mathrm{H}, \mathrm{PhCH}_{2} \mathrm{CH}_{2}\right) .{ }^{13} \mathrm{C}-\mathrm{NMR}\left(\mathrm{CDCl}_{3}\right) \delta 25.8(\mathrm{C}-3)$, 33.6 (C-2), $35.6\left(\mathrm{PhCH}_{2} \mathrm{CH}_{2}\right), 40.3(\mathrm{C}-4), 40.5\left(\mathrm{PhCH}_{2} \mathrm{CH}_{2}\right)$, $63.7\left(\mathrm{~d},{ }^{2} J_{\mathrm{C}, \mathrm{F}}=20.1 \mathrm{~Hz}, \mathrm{CH}_{2} \mathrm{CH}_{2} \mathrm{~F}\right), 81.8\left(\mathrm{~d},{ }^{1} J_{\mathrm{C}, \mathrm{F}}=169.5\right.$ $\mathrm{Hz}, \mathrm{CH}_{2} \mathrm{CH}_{2} \mathrm{~F}$ ), 126.4 (Ph-C4), 128.6 and 128.7 (Ph-C2,6 or Ph-C3,5), $138.8 \quad(\mathrm{Ph}-\mathrm{Cl}), \quad 156.4 \quad\left(\mathrm{COONHCH} \mathrm{NHCH}_{2}\right), 172.4$ $\left(\mathrm{NHCOCH}_{2}\right) \cdot{ }^{19} \mathrm{~F}-\mathrm{NMR}\left(\mathrm{CDCl}_{3}\right): \delta 224.6(\mathrm{tt}, J=29.4$ and $47.8 \mathrm{~Hz}$ ). ESI-MS m/z: $297[\mathrm{M}+\mathrm{H}]^{+} . \mathrm{C}_{15} \mathrm{H}_{21} \mathrm{~N}_{2} \mathrm{O}_{3}$ (296.34).

\section{3-[2-(3-Fluorophenyl)-ethylcarbamoyl]-propyl]-carbamic acid ethyl ester [10, 3-Fluoro phenethyl-Santacruzamate A]}

4-[(Ethoxycarbonyl)amino]butanoic acid (12a, $700 \mathrm{mg}, 4$ $\mathrm{mmol})$ was dissolved in anhydrous dichloromethane $(14 \mathrm{~mL})$ under argon atmosphere. The solution was cooled to $0{ }^{\circ} \mathrm{C}$. Triethylamine $(1.2 \mathrm{~mL}, 870 \mathrm{mg}, 8.6 \mathrm{mmol})$ and 3fluorophenethylamine $(0.6 \mathrm{~mL}, 4.6 \mathrm{mmol})$ were added consecutively. Afterwards EDC-HCl (900 mg, $4.7 \mathrm{mmol})$ was added in one portion. Catalytic amount DMAP $(30 \mathrm{mg})$ was added, the resulting mixture was stirred for $1 \mathrm{~h}$ at $0{ }^{\circ} \mathrm{C}$ and then for $16 \mathrm{~h}$ at room temperature. The reaction mixture was diluted with dichloromethane $(30 \mathrm{~mL})$ and consecutively washed with $1 \mathrm{M} \mathrm{HCl}$, saturated $\mathrm{NaHCO}_{3}$ solution and water $(20 \mathrm{~mL}$ of each). The combined extracts were dried $\left(\mathrm{Na}_{2} \mathrm{SO}_{4}\right)$ and evaporated to give an oily residue. The crude product was crystallized from hexane. - Yield: $723 \mathrm{mg}(61 \%) \mathrm{mp} .107-109^{\circ} \mathrm{C} . R_{f}[\mathrm{~A}]=0.58, R_{f}[\mathrm{~B}]=0.75$. ${ }^{1} \mathrm{H}-\mathrm{NMR}\left(\mathrm{CDCl}_{3}\right) \delta 1.22\left(\mathrm{t}, J=7.1 \mathrm{~Hz}, 3 \mathrm{H}, \mathrm{CH}_{3} \mathrm{CH}_{2} \mathrm{O}\right), 1.79$ (pent, $\left.J=6.8 \mathrm{~Hz}, 2 \mathrm{H}, 3-\mathrm{CH}_{2}\right), 2.17(\mathrm{t}, J=6.9 \mathrm{~Hz}, 2 \mathrm{H}, 2-$ $\mathrm{CH}_{2}$ ), 2.82 (t, $J=7.1 \mathrm{~Hz}, 2 \mathrm{H}, \mathrm{PhCH}_{2} \mathrm{CH}_{2}$ ), 3.17 (dd, $J=5.8$, $\left.11.8 \mathrm{~Hz}, 2 \mathrm{H}, 4-\mathrm{CH}_{2}\right), 3.51(\mathrm{dd}, J=7.0,13.0 \mathrm{~Hz}, 2 \mathrm{H}$, $\mathrm{PhCH}_{2} \mathrm{CH}_{2}$ ), 4.09 (q, $J=7.1 \mathrm{~Hz}, 2 \mathrm{H}, \mathrm{CH}_{3} \mathrm{CH}_{2} \mathrm{O}$ ), 4.92 (br s, $1 \mathrm{H}, \mathrm{NH}), 6.08$ (br s, $1 \mathrm{H}, \mathrm{NH}), 6.89-7.27(\mathrm{~m}, 5 \mathrm{H}$, $\left.\mathrm{PhCH}_{2} \mathrm{CH}_{2}\right) .{ }^{13} \mathrm{C}-\mathrm{NMR}\left(\mathrm{CDCl}_{3}\right) \delta=14.6\left(\mathrm{CH}_{3} \mathrm{CH}_{2} \mathrm{O}\right), 26.2$ (C-3), 33.5 (C-2), $35.3\left(\mathrm{PhCH}_{2} \mathrm{CH}_{2}\right), 40.0$ (C-4), 40.4 $\left(\mathrm{PhCH}_{2} \mathrm{CH}_{2}\right), 60.8\left(\mathrm{CH}_{3} \mathrm{CH}_{2} \mathrm{O}\right), 113.3\left(\mathrm{~d},{ }^{2} J_{\mathrm{C}, \mathrm{F}}=21 \mathrm{~Hz}, \mathrm{Ph}-\right.$ C4), $115.5\left(\mathrm{~d},{ }^{2} J_{\mathrm{C}, \mathrm{F}}=20.9 \mathrm{~Hz}, \mathrm{Ph}-C 2\right), 124.3\left(\mathrm{~d},{ }^{4} J_{\mathrm{C}, \mathrm{F}}=2.7\right.$ $\mathrm{Hz}, \mathrm{Ph}-\mathrm{C6}), 129.9$ (d, $\left.{ }^{3} J_{\mathrm{C}, \mathrm{F}}=8.3 \mathrm{~Hz}, \mathrm{Ph}-\mathrm{C} 5\right), 141.4\left(\mathrm{~d},{ }^{3} J_{\mathrm{C}, \mathrm{F}}\right.$ $=7.2 \mathrm{~Hz}, \mathrm{Ph}-C 1), 157.2(\mathrm{NHCOOEt}), 162.9$ (d, ${ }^{1} J_{\mathrm{C}, \mathrm{F}}=245.7$ $\mathrm{Hz}, \mathrm{Ph}-\mathrm{C} 3), 172.6\left(\mathrm{CH}_{2} \mathrm{CONH}\right) .-{ }^{19} \mathrm{~F}-\mathrm{NMR}\left(\mathrm{CDCl}_{3}\right): \delta=-$ $113.3-\mathrm{C}_{15} \mathrm{H}_{21} \mathrm{FN}_{2} \mathrm{O}_{3}(296.34)$.

\section{[3-[2-(3-Bromophenyl)-ethylcarbamoyl]-propyl]-carbamic acid ethyl ester (14, 3-bromophenethyl-Santacruzamate A)}

14 was prepared from 12a (1.9 g, $10.8 \mathrm{mmol})$ and 3bromophenethylamine according to the procedure described for compound 10. — Yield: $2.89 \mathrm{~g}(75 \%)$ - mp. 107-109 ${ }^{\circ} \mathrm{C}-R_{f}[\mathrm{~A}]=0.58, R f[\mathrm{~B}]=0.07, R_{f}[\mathrm{C}]=0.75-{ }^{1} \mathrm{H}-\mathrm{NMR}$ $\left(\mathrm{CDCl}_{3}\right) \delta=1.23\left(\mathrm{t}, J=7.1 \mathrm{~Hz}, 3 \mathrm{H}, \mathrm{CH}_{3} \mathrm{CH}_{2} \mathrm{O}\right), 1.79$ (pent, $\left.J=7.0 \mathrm{~Hz}, 2 \mathrm{H}, 3-\mathrm{CH}_{2}\right), 2.18\left(\mathrm{t}, J=6.9 \mathrm{~Hz}, 2 \mathrm{H}, 2-\mathrm{CH}_{2}\right), 2.80$ (t, $J=7.1 \mathrm{~Hz}, 2 \mathrm{H}, \mathrm{PhCH}_{2} \mathrm{CH}_{2}$ ), 3.17 (br m, 2H, 4- $\mathrm{CH}_{2}$ ), 3.50 (dd, $\left.J=7.0,13.0 \mathrm{~Hz}, 2 \mathrm{H}, \mathrm{PhCH}_{2} \mathrm{CH}_{2}\right), 4.09$ (q, $J=7.1 \mathrm{~Hz}$, $2 \mathrm{H}, \mathrm{CH}_{3} \mathrm{CH}_{2} \mathrm{O}$ ), 4.90 (br s, $1 \mathrm{H}, \mathrm{NH}$ ), 6.12 (br s, $1 \mathrm{H}, \mathrm{NH}$ ), 7.12-7.36 (m, 5H, PhCH $\left.\mathrm{CH}_{2}\right)$. - ${ }^{13} \mathrm{C}-\mathrm{NMR}\left(\mathrm{CDCl}_{3}\right) \delta=$ $14.6\left(\mathrm{CH}_{3} \mathrm{CH}_{2} \mathrm{O}\right), 26.3(\mathrm{C}-3), 33.5(\mathrm{C}-2), 35.2\left(\mathrm{PhCH}_{2} \mathrm{CH}_{2}\right)$, 40.0 (C-4), $40.4\left(\mathrm{PhCH}_{2} \mathrm{CH}_{2}\right), 60.8\left(\mathrm{CH}_{3} \mathrm{CH}_{2} \mathrm{O}\right), 122.5(\mathrm{Ph}-$ C-3), 127.4 (Ph-C-6), 129.6 (Ph-C4), 130.1 (Ph-C-5), 131.8

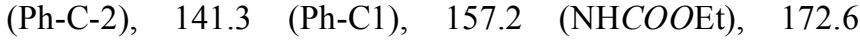
$\left(\mathrm{CH}_{2} \mathrm{CONH}\right) .-\mathrm{C}_{15} \mathrm{H}_{21} \mathrm{BrN}_{2} \mathrm{O}_{3}(357.24)$.

\section{2-(2-Pyridinyl)-2-nitrobenzenesulfonanilide [33]}

The free base of 2-(2-pyridinyl)aniline (CAS RN: [29528-30-1]) was liberated from its dihydrochloride salt (1.5 g, $6.17 \mathrm{mmol}$, CAS RN: 18471-73-3]). Yield: $1.05 \mathrm{~g}$ (quant). 2-(2-pyridinyl)aniline (1.05 $\mathrm{g}, 6.17 \mathrm{mmol})$ was dissolved in anhydrous dichloromethane $(10 \mathrm{~mL})$ under argon. The solution was cooled down to $0{ }^{\circ} \mathrm{C}$ and pyridine $(2$ $\mathrm{mL}$ ) was added. 2-Nitrobenzenesulfonylchloride $(2.7 \mathrm{~g}, 12.1$ $\mathrm{mmol}$ ) was given and the mixture was stirred for $2 \mathrm{~h}$ at room temperature. The reaction mixture was poured on to water $(40 \mathrm{~mL})$ and the resulting suspension was extracted with dichloromethane $(3 \times 50 \mathrm{~mL})$. The combined organic layer was washed with brine $(50 \mathrm{~mL})$ and dried $\left(\mathrm{Na}_{2} \mathrm{SO}_{4}\right)$. The solvent was removed under diminished pressure to yield a yellowish oily residue (ca. $3.39 \mathrm{~g}$ ). The crude product was 
purified by column chromatography on silica gel (Kieselgel: $100 \mathrm{~g}$, eluent: hexane-ethyl acetate 7:3 (v/v), fractions: 50 $\mathrm{mL})$. The purified product $(1.89 \mathrm{~g})$ was crystallized from diethyl-ether $(25 \mathrm{~mL})$. Yield: $1.35 \mathrm{~g}(61 \%) .-R_{f}[\mathrm{~B}]=$ $0.47, R_{f}[\mathrm{D}]=0.23 .-{ }^{1} \mathrm{H}-\mathrm{NMR}\left(\mathrm{CDCl}_{3}\right) \delta=7.18(\mathrm{dt}, J=7.7$ $\mathrm{Hz}, 1.1 \mathrm{~Hz}, 1 \mathrm{H}), 7.24$ (ddd, $J=7.5 \mathrm{~Hz}, 7.5 \mathrm{~Hz}, 1.0 \mathrm{~Hz}, 1 \mathrm{H})$, 7.37 (dt, $J=7.7 \mathrm{~Hz}, 1.4 \mathrm{~Hz}, 1 \mathrm{H}), 7.51-7.62(\mathrm{~m}, 5 \mathrm{H}), 7.73$ (dt, $J=7.8 \mathrm{~Hz}, 1.8 \mathrm{~Hz}, 1 \mathrm{H}), 7.81(\mathrm{dd}, J=8.3 \mathrm{~Hz}, 0.9 \mathrm{~Hz}$, $1 \mathrm{H}), 7.92(\mathrm{dd}, J=7.6 \mathrm{~Hz}, 1.5 \mathrm{~Hz}, 1 \mathrm{H}), 8.72(\mathrm{dd}, J=4.9 \mathrm{~Hz}$, $0.9 \mathrm{~Hz}, 1 \mathrm{H}), 13.0$ (br s, $1 \mathrm{H}) .-{ }^{13} \mathrm{C}-\mathrm{NMR}\left(\mathrm{CDCl}_{3}\right) \delta=$ $121.6,121.7,122.1,124.5,124.7,126.8,128.8,130.1,130.7$, $131.9,133.2,133.3,136.1,137.6,147.7,156.6$. $\mathrm{C}_{17} \mathrm{H}_{13} \mathrm{~N}_{3} \mathrm{O}_{4} \mathrm{~S}$ (355.37).

\section{[2-(2-Pyridinyl)phenyl-2-nitrobenzenesulfonamide] silver(I) (17, CAS RN: [1403599-78-9]) [33]}

Silver(I) oxide (410 $\mathrm{mg}, 1.75 \mathrm{mmol})$ was suspended in dry acetonitrile $(7 \mathrm{~mL})$ under argon atmosphere. A solution of 2-(2-pyridinyl)phenyl-2-nitrobenzenesulfonanilide (1.25 $\mathrm{g}, 3.5 \mathrm{mmol})$ in dry acetonitrile $(10 \mathrm{~mL})$ was added dropwise at room temperature. The reaction mixture was stirred at 65 ${ }^{\circ} \mathrm{C}$ for $16 \mathrm{~h}$. The mixture was filtered and the filtrate was evaporated to dryness. Dry hexane $(60 \mathrm{~mL})$ was added to the residue and the precipitated product was filtered off. The product was dried in vacuo. Yield: $1.45 \mathrm{~g}(89 \%)$. - ${ }^{1} \mathrm{H}-$ $\operatorname{NMR}\left(\mathrm{CDCl}_{3}\right) \delta=6.73(\mathrm{~d}, J=7.0 \mathrm{~Hz}, 1 \mathrm{H}), 6.86(\mathrm{~d}, J=6.8$ $\mathrm{Hz}, 1 \mathrm{H}), 7.08$ (d, $J=7.0 \mathrm{~Hz}, 1 \mathrm{H}), 7.2$ (t, $J=7.3 \mathrm{~Hz}, 1 \mathrm{H})$, 7.25-7.31 (m, 3H), 7.35-7.38 (m, 1H), 7.43-7.48 (m, 3H), 8.61 (br s, $1 \mathrm{H})$. $-\mathrm{C}_{17} \mathrm{H}_{12} \mathrm{AgN}_{3} \mathrm{O}_{4} \mathrm{~S}$ (462.23).

\section{Nickel [\{3-[2-(3-substituted-phenyl)-ethylcarbamoyl]-propyl\}- carbamic acid ethyl ester] bromid complex (15)}

[3-[2-(3-Bromophenyl)-ethylcarbamoyl]-propyl]-carbamic acid ethyl ester $(\mathbf{1 4}, 512 \mathrm{mg}, 1.43 \mathrm{mmol})$ was dissolved in dry toluene $(16 \mathrm{~mL})$ under argon. TMEDA $(0.22 \mathrm{~mL}, 1.43$ mmol) and $\mathrm{Ni}(\mathrm{COD})_{2}$ were added consecutively and the reaction mixture was stirred at room temperature for $16 \mathrm{~h}$. Pentane $(64 \mathrm{~mL})$ was added and the mixture was stirred for $15 \mathrm{~min}$ at RT. The precipitated solid was filtered and dried in vacuo. Yield: $619 \mathrm{mg}(81 \%)$ as beige solid - ${ }^{1} \mathrm{H}-\mathrm{NMR}$ and ${ }^{13} \mathrm{C}-\mathrm{NMR}$ spectra were not obtained due to the low solubility of the product.

\section{Nickel [\{3-[2-(3-substituted-phenyl)-ethylcarbamoyl]-propyl\}- carbamic acid ethyl ester] complex (16, 3-(Phenethyl- Santacruzamate A)-nickel aryl complex)}

To a mixture of [2-(2-Pyridinyl)phenyl-2-nitrobenzenesulfonamide]silver(I) (17, $227 \mathrm{mg}, 0.49 \mathrm{mmol}, 1$ equiv) and the nickel aryl bromide complex 15 (260 mg, $0.49 \mathrm{mmol}, 1$ equiv) a solution of dry pyridine was added $(79 \mu \mathrm{L}, 0.98$ mmol, 2 equiv) in dry toluene $(4 \mathrm{~mL})$ under argon atmosphere. Dry acetonitrile $(1 \mathrm{~mL})$ was added and the mixture stirred at ambient temperature for $3 \mathrm{~min}$. Thereafter, the solution was filtered and the cake was washed with dry dichloromethane $(3 \times 5 \mathrm{~mL})$. The solvent was evaporated in vacuo and the residue was redissolved in dry dichloromethane $(8 \mathrm{~mL})$. The solution was filtered through Celite (ca. $2 \mathrm{~g})$ and the filtrate was concentrated in vacuo. The residue was dissolved in dry dichloromethane $(3 \mathrm{~mL})$ under argon and $n$ pentane $(17 \mathrm{~mL})$ was given. The mixture was stirred at room temperature and the precipitate was filtered off (under argon atmosphere). The product was washed with pentane $(3 \times 5$ $\mathrm{mL}$ ) and dried in vacuo. Yield: $328 \mathrm{mg}(87 \%)$ as yellow solid -

${ }^{1} \mathrm{H}-\mathrm{NMR}\left(\mathrm{CDCl}_{3}\right) \delta=1.23(\mathrm{t}, J=7.0 \mathrm{~Hz}, 3 \mathrm{H}$, $\mathrm{CH}_{3} \mathrm{CH}_{2} \mathrm{O}$ ), 1.79 (pent, $J=7.0 \mathrm{~Hz}, 2 \mathrm{H}, 3-\mathrm{CH}_{2}$ ), 2.17 (t, $J=$ $\left.7.0 \mathrm{~Hz}, 2 \mathrm{H}, 2-\mathrm{CH}_{2}\right), 2.80\left(\mathrm{t}, J=7.0 \mathrm{~Hz}, 2 \mathrm{H}, \mathrm{PhCH}_{2} \mathrm{CH}_{2}\right)$, $3.18\left(\mathrm{dd}, J=12.6 \mathrm{~Hz}, 6.2 \mathrm{~Hz}, 2 \mathrm{H}, 4-\mathrm{CH}_{2}\right), 3.50$ (dd, $J=13.0$ $\left.\mathrm{Hz}, 7.0 \mathrm{~Hz}, 2 \mathrm{H}, \mathrm{PhCH}_{2} \mathrm{CH}_{2}\right), 4.09$ (q, $J=7.0 \mathrm{~Hz}, 2 \mathrm{H}$, $\left.\mathrm{CH}_{3} \mathrm{CH}_{2} \mathrm{O}\right), 4.90$ (br s, $\left.1 \mathrm{H}, \mathrm{NH}\right), 6.08$ (br s, $\left.1 \mathrm{H}, \mathrm{NH}\right), 6.77(\mathrm{~d}$, $J=7.3 \mathrm{~Hz}, 1 \mathrm{H}), 6.97(\mathrm{~d}, J=7.5 \mathrm{~Hz}, 1 \mathrm{H}), 7.09(\mathrm{~d}, J=7.3 \mathrm{~Hz}$, $1 \mathrm{H}), 7.12-7.18\left(\mathrm{~m}, 3 \mathrm{H}, \mathrm{PhCH}_{2} \mathrm{CH}_{2}\right), 7.24-7.32(\mathrm{~m}, 5 \mathrm{H})$, 7.34-7.36 (m, 2H, $\left.\mathrm{PhCH}_{2} \mathrm{CH}_{2}\right), 7.37-7.39(\mathrm{~m}, 1 \mathrm{H}), 7.42-7.50$ $(\mathrm{m}, 4 \mathrm{H}), 7.69$ (br t, 1H), 8.57-8.60 (m, 2H). - ${ }^{13} \mathrm{C}-\mathrm{NMR}$ $\left(\mathrm{CDCl}_{3}\right) \delta=14.6\left(\mathrm{CH}_{3} \mathrm{CH}_{2} \mathrm{O}\right), 26.3(\mathrm{C}-3), 33.6(\mathrm{C}-2), 35.3$ $\left(\mathrm{PhCH}_{2} \mathrm{CH}_{2}\right), 40.0$ (C-4), $40.4\left(\mathrm{PhCH}_{2} \mathrm{CH}_{2}\right), 60.8\left(\mathrm{CH}_{3}\right.$ $\mathrm{CH}_{2} \mathrm{O}$ ), 122.4, 122.5 (Ph-C-3), 123.1, 123.8, 124.6, 126.0, 127.4 (Ph-C-6), 129.6 (Ph-C4), 129.7, 130.1 (Ph-C-5), 130.3, $130.4,130.5,130.6,130.7,131.8$ (Ph-C-2), 136.1, 137.0, 137.6, 138.1, 141.3 (Ph-C1), 143.1, 147.6, 150.0, 150.4, 157.2 (NHCOOEt), 161.1, $172.5\left(\mathrm{CH}_{2} \mathrm{CONH}\right) .-\mathrm{C}_{37} \mathrm{H}_{38} \mathrm{~N}_{6}$ $\mathrm{NiO}_{7} \mathrm{~S}(769.49)$.

\section{Synthesis of the Hypervalent Iodine Oxidant [33, 42]}

\section{1,1'-(Phenyl- $\lambda^{3}$-iodanediyl)-bis(4-methoxypyridinium)- bis(trifluormethansulfonate) (18)}

18 was synthesized according to the procedure of Weiß and Seubert [42]. All operations were carried out in a dry reaction vessel in anhydrous solvent under argon atmosphere. (Diacetoxyiodo)benzene $(3.0 \mathrm{~g}, 9.3 \mathrm{mmol})$ was dissolved in dichloromethane $(100 \mathrm{~mL})$ under argon atmosphere. Trimethylsilyl trifluormethansulfonate $(3.4 \mathrm{~mL}, 18.6 \mathrm{mmol})$ was added dropwise to this solution at ambient temperature. A solution of 4-methoxypyridine $(1.9 \mathrm{~mL}, 2.03 \mathrm{~g}, 18.6$ $\mathrm{mmol})$ in dihloromethan $(15 \mathrm{~mL})$ was dropped in and the reaction mixture was stirred for $15 \mathrm{~min}$ at room temperature. The solvent was removed under diminished pressure and anhydrous diethyl ether $(100 \mathrm{~mL})$ was given to the residue. The mixture was stirred for $1 \mathrm{~h}$ under argon, the precipitated solid was filtered off and washed with dry diethyl ether (40 $\mathrm{mL})$. The product was dried in vacuo $\left(3 \times 10^{-1} \mathrm{mbar}, 16 \mathrm{~h}\right)$. Yield: $6.06 \mathrm{~g}(90 \%)$ off white solid. $-{ }^{1} \mathrm{H}-\mathrm{NMR}\left(\mathrm{CD}_{3} \mathrm{CN}\right) \delta$ $=4.04\left(\mathrm{~s}, 6 \mathrm{H}, 2 \times \mathrm{OCH}_{3}\right), 7.30(\mathrm{~d}, J=6.5 \mathrm{~Hz}, 4 \mathrm{H}, \mathrm{H}-3,5$ pyridine), 7.36 (t, $J=\mathrm{Hz}, 7.5 \mathrm{H}, \mathrm{H}-2,6 \mathrm{Ph}), 7.56$ (t, $J=7.5$ $\mathrm{Hz}, 1 \mathrm{H}, \mathrm{H}-4 \mathrm{Ph}), 7.85$ (d, $J=\mathrm{Hz}, 2 \mathrm{H}, \mathrm{H}-3,5 \mathrm{Ph}), 8.43$ (d, $J=$ $7.5 \mathrm{~Hz}, 4 \mathrm{H}, \mathrm{H}-2,6$ pyridine $) .-{ }^{13} \mathrm{C}-\mathrm{NMR}\left(\mathrm{CDCl}_{3}\right) \delta=58.9$ $\left(\mathrm{OCH}_{3}\right), 94.8(\mathrm{C}-1 \mathrm{Ph}), 114.0(\mathrm{C}-3,5$ pyridine $), 122.1$ (q, $J_{\mathrm{C}, \mathrm{F}}$ $\left.=320.7 \mathrm{~Hz}, \mathrm{CF}_{3} \mathrm{SO}_{3}\right), 128.8(\mathrm{C}-4 \mathrm{Ph}), 131.6(\mathrm{C}-3,5 \mathrm{Ph})$, 138.5 (C-2,6 Ph), $144.0 \quad(\mathrm{C}-2,6$ pyridine), $173.8 \quad(\mathrm{C}-4$ pyridine). $-{ }^{19} \mathrm{~F}-\mathrm{NMR}\left(\mathrm{CDCl}_{3}\right): \delta=-79.3-\mathrm{C}_{20} \mathrm{H}_{19}$ $\mathrm{F}_{6} \mathrm{IN}_{2} \mathrm{O}_{8} \mathrm{~S}_{2}(720.40)$.

\section{SUPPLEMENTARY MATERIAL}

Supplementary material is available on the publisher's web site along with the published article.

\section{CONFLICT OF INTEREST}

The authors confirm that this article content has no conflict of interest. 


\section{ACKNOWLEDGEMENTS}

MS is supported by a "Waxweiler grant for cancer prevention research" from the Action Lions "Vaincre le Cancer". This work was supported by the "Recherche Cancer et Sang" foundation, the "Recherches Scientifiques Luxembourg" association, by the "Een Häerz fir kriibskrank Kanner" association, by the Action LIONS "Vaincre le Cancer" association and by Télévie Luxembourg. MD is supported by the NRF by the MEST of Korea for Tumor Microenvironment GCRC 2012-0001184 grant and by Brain Korea (BK21) PLUS program. LRM and FOL are supported by The Norwegian Council on Cardiovascular Diseases, The Research Council of Norway, The Kristian Gerhard Jebsen foundation, Anders Jahre's Foundation for the Promotion of Science, The Family Blix foundation, The Simon Fougner Hartmann family foundation and grants from the University of Oslo. MA and KV are supported by IMIR (In Vivo Molecular Imaging Research group) at KU Leuven, Belgium.

\section{REFERENCES}

[1] Minucci, S.; Pelicci, P. G. Histone Deacetylase Inhibitors and the Promise of Epigenetic (and More) Treatments for Cancer. Nat. Rev. Cancer 2006, 6 (1), 38-51.

[2] Bertrand, P. Inside HDAC with HDAC Inhibitors. Eur. J. Med. Chem. 2010, 45 (6), 2095-2116.

[3] Seidel, C.; Florean, C.; Schnekenburger, M.; Dicato, M.; Diederich, M. Chromatin-Modifying Agents in Anti-Cancer Therapy. Biochimie 2012, 94 (11), 2264-2279.

[4] Folmer, F.; Orlikova, B.; Schnekenburger, M.; Dicato, M.; Diederich, M. Naturally Occurring Regulators of Histone Acetylation/ Deacetylation. Curr. Nutr. Food Sci. 2010, 6 (1), 78-99.

[5] Abend, A.; Kehat, I. Histone Deacetylases as Therapeutic Targets - From Cancer to Cardiac Disease. Pharmacol. Ther. 2015, 147, 55-62.

[6] Florean, C.; Schnekenburger, M.; Grandjenette, C.; Dicato, M.; Diederich, M. Epigenomics of Leukemia: From Mechanisms to Therapeutic Applications. Epigenomics 2011, 3 (5), 581-609.

[7] Schnekenburger, M.; Dicato, M.; Diederich, M. Epigenetic Modulators from "The Big Blue": A Treasure to Fight against Cancer. Cancer Lett. 2014, 351 (2), 182-197.

[8] Kazantsev, A. G.; Thompson, L. M. Therapeutic Application of Histone Deacetylase Inhibitors for Central Nervous System Disorders. Nat. Rev. Drug Discov. 2008, 7 (10), 854-868.

[9] Seidel, C.; Schnekenburger, M.; Dicato, M.; Diederich, M. Histone Deacetylase Modulators Provided by Mother Nature. Genes Nutr. 2012, 7 (3), 357-367.

[10] West, A. C.; Johnstone, R. W. New and Emerging HDAC Inhibitors for Cancer Treatment. J. Clin. Invest. 2014, 124 (1), 30-39.

[11] Wagner, F. F.; Weïwer, M.; Lewis, M. C.; Holson, E. B. Small Molecule Inhibitors of Zinc-Dependent Histone Deacetylases. Neurotherapeutics 2013, 10 (4), 589-604.

[12] Schnekenburger, M.; Florean, C.; Dicato, M.; Diederich, M. Epigenetic Alterations as a Universal Feature of Cancer Hallmarks and a Promising Target for Personalized Treatments. Curr. Top. Med. Chem. 2015, 16 (7), 745-776.

[13] Thaler, F.; Mercurio, C. Towards Selective Inhibition of Histone Deacetylase Isoforms: What Has Been Achieved, Where We Are and What Will Be Next. ChemMedChem 2014, 9 (3), 523-536.

[14] Zhang, L.; Han, Y.; Jiang, Q.; Wang, C.; Chen, X.; Li, X.; Xu, F.; Jiang, Y.; Wang, Q.; Xu, W. Trend of Histone Deacetylase Inhibitors in Cancer Therapy: Isoform Selectivity or Multitargeted Strategy. Med. Res. Rev. 2015, 35 (1), 63-84.

[15] Felice, C.; Lewis, A.; Armuzzi, A.; Lindsay, J. O.; Silver, A. Review Article: Selective Histone Deacetylase Isoforms as Potential Therapeutic Targets in Inflammatory Bowel Diseases. Aliment. Pharmacol. Ther. 2015, 41 (1), 26-38.

[16] Gupta, P.; C. Reid, R.; Iyer, A.; J. Sweet, M.; P. Fairlie, D. Towards Isozyme-Selective HDAC Inhibitors For Interrogating Disease. Curr. Top. Med. Chem. 2012, 12 (14), 1479-1499.
[17] SONG, J.; NOH, J. H.; LEE, J. H.; EUN, J. W.; AHN, Y. M.; KIM, S. Y.; LEE, S. H.; PARK, W. S.; YOO, N. J.; LEE, J. Y.; NAM, S. W. Increased Expression of Histone Deacetylase 2 Is Found in Human Gastric Cancer. APMIS 2005, 113 (4), 264-268.

[18] Zhu, P.; Martin, E.; Mengwasser, J.; Schlag, P.; Janssen, K.-P.; Göttlicher, M. Induction of HDAC2 Expression upon Loss of APC in Colorectal Tumorigenesis. Cancer Cell 2004, 5 (5), 455-463.

[19] Ravillah, D.; Mohammed, A.; Qian, L.; Brewer, M.; Zhang, Y.; Biddick, L.; Steele, V. E.; Rao, C. V. Chemopreventive Effects of an HDAC2-Selective Inhibitor on Rat Colon Carcinogenesis and APCmin/+ Mouse Intestinal Tumorigenesis. J. Pharmacol. Exp. Ther. 2013, 348 (1), 59-68.

[20] Krämer, O. H. HDAC2: A Critical Factor in Health and Disease. Trends Pharmacol. Sci. 2009, 30 (12), 647-655.

[21] Falkenberg, K. J.; Johnstone, R. W. Histone Deacetylases and Their Inhibitors in Cancer, Neurological Diseases and Immune Disorders. Nat. Rev. Drug Discov. 2014, 13 (9), 673-691.

[22] Wagner, T.; Brand, P.; Heinzel, T.; Krämer, O. H. Histone Deacetylase 2 Controls p53 and Is a Critical Factor in Tumorigenesis. Biochim. Biophys. Acta - Rev. Cancer 2014, 1846 (2), 524-538.

[23] Gräff, J.; Rei, D.; Guan, J.-S.; Wang, W.-Y.; Seo, J.; Hennig, K. M.; Nieland, T. J. F.; Fass, D. M.; Kao, P. F.; Kahn, M.; Su, S. C.; Samiei, A.; Joseph, N.; Haggarty, S. J.; Delalle, I.; Tsai, L.-H. An Epigenetic Blockade of Cognitive Functions in the Neurodegenerating Brain. Nature 2012, 483 (7388), 222-226.

[24] Eom, G. H.; Kook, H. Role of Histone Deacetylase 2 and Its Posttranslational Modifications in Cardiac Hypertrophy. BMB Rep. 2015, 48 (3), 131-138.

[25] Gopalan, B.; Ponpandian, T.; Kachhadia, V.; Bharathimohan, K.; Vignesh, R.; Sivasudar, V.; Narayanan, S.; Mandar, B.; Praveen, R.; Saranya, N.; Rajagopal, S.; Rajagopal, S. Discovery of Adamantane Based Highly Potent HDAC Inhibitors; 2013; Vol. 23. Wang, C.; Schroeder, F. A.; Wey, H.-Y.; Borra, R.; Wagner, F. F.; Reis, S.; Kim, S. W.; Holson, E. B.; Haggarty, S. J.; Hooker, J. M. In Vivo Imaging of Histone Deacetylases (HDACs) in the Central Nervous System and Major Peripheral Organs. J. Med. Chem. 2014, 57 (19), 7999-8009.

[27] Strebl, M. G.; Wang, C.; Schroeder, F. A.; Placzek, M. S.; Wey, H.-Y.; Van de Bittner, G. C.; Neelamegam, R.; Hooker, J. M. Development of a Fluorinated Class-I HDAC Radiotracer Reveals Key Chemical Determinants of Brain Penetrance. ACS Chem. Neurosci. 2016, 7 (5), 528-533.

[28] Pavlik, C. M.; Wong, C. Y. B.; Ononye, S.; Lopez, D. D.; Engene, N.; McPhail, K. L.; Gerwick, W. H.; Balunas, M. J. Santacruzamate A, a Potent and Selective Histone Deacetylase Inhibitor from the Panamanian Marine Cyanobacterium Cf. Symploca Sp. J. Nat. Prod. 2013, 76 (11), 2026-2033.

[29] Ononye, S. N.; VanHeyst, M. D.; Giardina, C.; Wright, D. L.; Anderson, A. C. Studies on the Antiproliferative Effects of Tropolone Derivatives in Jurkat T-Lymphocyte Cells. Bioorg. Med. Chem. 2014, 22 (7), 2188-2193.

[30] Ononye, S. N.; VanHeyst, M. D.; Oblak, E. Z.; Zhou, W.; Ammar, M.; Anderson, A. C.; Wright, D. L. Tropolones As Lead-Like Natural Products: The Development of Potent and Selective Histone Deacetylase Inhibitors. ACS Med. Chem. Lett. 2013, 4 (8), 757-761.

[31] Liu, Q.; Lu, W.; Ma, M.; Liao, J.; Ganesan, A.; Hu, Y.; Wen, S.; Huang, P. Synthesis and Biological Evaluation of Santacruzamate A and Analogs as Potential Anticancer Agents. RSC Adv. 2015, 5 (2), 1109-1112.

[32] Pérez, E. R.; da Silva, M. O.; Costa, V. C.; Rodrigues-Filho, U. P.; Franco, D. W. Efficient and Clean Synthesis of $\mathrm{N}$-Alkyl Carbamates by Transcarboxylation and O-Alkylation Coupled Reactions Using a DBU-CO2 Zwitterionic Carbamic Complex in Aprotic Polar Media; 2002; Vol. 43.

[33] Lee, E.; Hooker, J. M.; Ritter, T. Nickel-Mediated Oxidative Fluorination for PET with Aqueous $\left[{ }^{18}\right.$ F] Fluoride. J. Am. Chem. Soc. 2012, 134 (42), 17456-17458.

[34] Shi, P.; Scott, M. A.; Ghosh, B.; Wan, D.; Wissner-Gross, Z.; Mazitschek, R.; Haggarty, S. J.; Yanik, M. F. Synapse Microarray Identification of Small Molecules That Enhance Synaptogenesis. Nat. Commun. 2011, 2, 510 .

[35] Vigushin, D. M.; Ali, S.; Pace, P. E.; Mirsaidi, N.; Ito, K.; Adcock, I.; Coombes, R. C. Trichostatin A Is a Histone Deacetylase 
Inhibitor with Potent Antitumor Activity against Breast Cancer in Vivo. Clin. Cancer Res. 2001, 7 (4), 971-976.

[36] El Amrani, M.; Lai, D.; Debbab, A.; Aly, A. H.; Siems, K.; Seidel, C.; Schnekenburger, M.; Gaigneaux, A.; Diederich, M.; Feger, D.; Lin, W.; Proksch, P. Protein Kinase and HDAC Inhibitors from the Endophytic Fungus Epicoccum Nigrum. J. Nat. Prod. 2014, 77 (1), 49-56.

[37] Seidel, C.; Schnekenburger, M.; Dicato, M.; Diederich, M. Antiproliferative and Proapoptotic Activities of 4-Hydroxybenzoic Acid-Based Inhibitors of Histone Deacetylases. Cancer Lett. 2014, 343 (1), 134-146.

[38] Nussinov and Chung-Jung Tsai, R. The Different Ways through Which Specificity Works in Orthosteric and Allosteric Drugs. Curr. Pharm. Des. 2012, 18 (9).

[39] Alonso, H.; Bliznyuk, A. A.; Gready, J. E. Combining Docking and Molecular Dynamic Simulations in Drug Design. Med. Res. Rev. 2006, 26 (5), 531-568.
[40] Lauffer, B. E. L.; Mintzer, R.; Fong, R.; Mukund, S.; Tam, C.; Zilberleyb, I.; Flicke, B.; Ritscher, A.; Fedorowicz, G.; Vallero, R.; Ortwine, D. F.; Gunzner, J.; Modrusan, Z.; Neumann, L.; Koth, C. M.; Lupardus, P. J.; Kaminker, J. S.; Heise, C. E.; Steiner, P. Histone Deacetylase (HDAC) Inhibitor Kinetic Rate Constants Correlate with Cellular Histone Acetylation but Not Transcription and Cell Viability. J. Biol. Chem. 2013, 288 (37), 26926-26943.

[41] Pan, D.-S.; Yang, Q.-J.; Fu, X.; Shan, S.; Zhu, J.-Z.; Zhang, K.; Li, Z.-B.; Ning, Z.-Q.; Lu, X.-P. Discovery of an Orally Active Subtype-Selective HDAC Inhibitor, Chidamide, as an Epigenetic Modulator for Cancer Treatment. Med. Chem. Commun. 2014, 5 (12), 1789-1796

[42] Weiss, R.; Seubert, J. Electrostatic Activation of Hypervalent Organo-Iodine Compounds: Bis(onio)-Substituted Aryliodine(III) Salts. Angew. Chemie Int. Ed. English 1994, 33 (8), 891-893. 